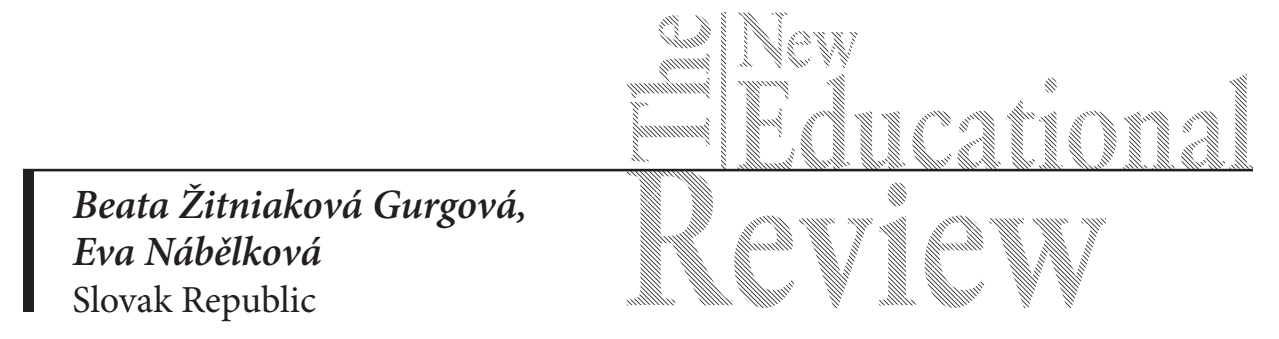

\title{
Typology of Undergraduate Students by Academic Performance and Aspects of Achievement Motivation
}

DOI: 10.15804/tner.2017.47.1.01

\begin{abstract}
The contribution presents results of the non-hierarchical cluster analysis of academic performance and aspects of achievement motivation of a sample of undergraduate students. The Achievement Motivation Questionnaire (AMQ) (Dotazník motivácie výkonu, Pardel, Maršálová, Hrabovská, 1984) was used as the research method. School success was established using the arithmetic mean of study results of 213 undergraduate students after completion of a term. In the AMQ, the Achievement Motive variable was focused on, consisting of the following aspects: achievement- oriented behaviour, aspiration level, perseverance at work, and future time orientation. The main aim of our research was to determine undergraduate student types by their academic performance and aspects of achievement motive. Based on the assessment of generated three to six-cluster solutions, the six-cluster solution appeared optimal, within which the following types of undergraduate students were identified: type of unused potential, unbalanced type, balanced type, type unoriented in time, academically indifferent type, and industrious type.
\end{abstract}

Keywords: achievement motivation, achievement motive, academic performance, undergraduate student types, cluster analysis 


\section{Problem}

According to McClelland's model (1976), achievement motivation may be understood as a relatively stable predisposition of an individual, representing one of important achievement factors. Achievement motives represent a general, affectbased disposition triggering the achievement activity and leading an individual to success or failure. The basis of achievement motivation is the need for achievement and the fear of failure, predisposing individuals to a different type of achievement goals. The achievement goals then affect the achievement-oriented behaviour of an individual (Elliot; in Neumeister, Finch, 2006). According to Hermans's conception, the achievement motive is made up of four basic components, namely: the achievement-oriented behaviour, aspiration level, perseverance at work, and future time orientation (Pardel, Maršálová, Hrabovská, 1984). In our opinion, research on achievement motivation at the level of individual components of the achievement motive is meaningful also in relation to academic performance. Findings regarding a linear relationship between achievement motivation and academic performance are contradictory or mostly statistically insignificant (cf., the studies by: Kolb, 1965; Řehulková, Osecká, 1996; Skinner, J. M. Drake, 2003; Gurgová, 2005).

That was the reason why we decided to use cluster analysis, which helped us to identify empirical types and specific configurations of individual components of the achievement motive and level of academic performance.

\section{Research sample}

The aim of our research was to determine types of undergraduate students by their academic performance and individual aspects of the achievement motive. The research sample was obtained by targeted and occasional sampling, and consisted of 213 undergraduate students of social and technological majors in Banská Bystrica and Liptovský Mikuláš, with an average age of 20.5 years. The research sample was composed of 102 women and 111 men.

\section{Methods}

The method of our research consisted of the standardized AMQ - Achievement Motivation Questionnaire, constructed on the basis of Hermans's conception of achievement motivation. The normalizing sample of undergraduate students was 
calculated the following coefficients of internal reliability: 0.87 for the variable achievement motive, 0.85 for the variable anxiety with debilitating effects on performance, and 0.88 for the variable anxiety facilitating performance. Validity of the questionnaire was tested using Ehlers and Merz's questionnaire for the measurement of achievement motivation and Spielberg's questionnaire of anxiety as a trait. In both cases, sufficiently high correlation coefficients were produced, evidentiary for validity of the given type.

The questionnaire contains 52 items and consists of three scales: the scale of achievement motive ( 24 items), the scale of anxiety with debilitating effects on performance (17 items), and the scale of anxiety facilitating performance (10 items).

The achievement motive is characterized by the following aspects: Achievement-oriented Behaviour, consisting of 8 items such as: "I like to work", or "My friends and acquaintances consider me diligent"; Aspiration Level consisting of 5 items such as: "I don't avoid work requiring responsibility" or "When I do something, it must be perfect"; Perseverance at Work consisting of 5 items: "Persistence is a very important characteristic" or "Once I have set to hard work, I can hardly stop"; Future Time Orientation consisting of 6 items, such as: "I like to plan" or "In general I'm focused on future". The achievement motive scale is a relatively heterogeneous scale (Pardel, Maršálová, Hrabovská, 1984).

Due to the fact that there are certain contradictions in the conception of school success, we focused on actual school success operationally defined as good study results obtained by a student, measurable through the average of examination evaluations, thus as academic performance. Academic performance was used in measurements of school success by several authors, such as S. Shim and A. Ryan (2005), W. E. Kelly (2003), T. L. Clemons (2005), K. E. Barron et al. (2006) and others. Thus, school success was determined by means of the arithmetic mean of study results after an examination period of a relevant term, while taking into account also the evaluation $\mathrm{Fx}$ - failed. Numbers assigned to individual evaluation grades were as follows: A $-1, \mathrm{~B}-1.5, \mathrm{C}-2, \mathrm{D}-2.5, \mathrm{E}-3, \mathrm{Fx}-4$. The students were given the instruction to fill in the determined place in the questionnaire with the total average of their evaluations for the last term as displayed in the academic information system.

The quantitative data obtained were evaluated using the IBM computer program SPSS Statistics 19 and Microsoft Excel. 


\section{Methodological Issues of the Problem Addressed}

To determine student types by academic performance and the achievement motive aspects including: achievement-oriented behaviour, aspiration level, perseverance at work and future time orientation, cluster analysis was used. In the cluster analysis, data were standardized to the z-score and a non-hierarchical analysis was used. Cluster analysis is a set of methods enabling one to look for clusters of similar objects - types in empirical data. L. Osecká (2001) states that the use of cluster analysis is particularly appropriate at the stage of problem exploration. As opposed to factor analysis, when using cluster analysis mostly no attention is given to basic dimensions of the description of the phenomena studied (variables), but attention is given to basic types of the studied phenomena as such (objects), their similarity or dissimilarity (although sometimes it is problematic to define what precisely the similarity is).

The most well-known non-hierarchical clustering method is the k-means method. This method is characteristic of producing an exact number of $\mathrm{k}$ clusters so that the intra-group sum of squares of distances of objects is minimal. It requires a priori setting of the number of clusters to be generated, and interval variables without extreme values as the input (Osecká, 2001). The mentioned $\mathrm{k}$-means method was used also in the processing of our research data.

\section{Results of Cluster Analysis by Academic Performance and Achievement Motive}

The main aim of our research was to determine types of students by academic performance and by the aspects of the achievement motive including achievement-oriented behaviour, aspiration level, perseverance at work and future time orientation. The given aspects were obtained by item analysis within the achievement motive scale of the AMQ questionnaire. To overcome disunity of the scales (the scales measuring the achievement motive components did not offer respondents the same number of response options), the obtained raw scores were standardized. These standardized scores (so-called z-scores) with the mean value 0 and standard deviation 1 were processed by further statistical analysis. Non-hierarchical cluster analysis, the k-means method (in the statistical program SPSS) was used and a typology created gradually for three, four, five and six types or clusters.

Mean z-scores of the types in the three-cluster solution differ from each other the least in the variable of academic performance; the values oscillate around 0. 
Profiles of the mean $\mathrm{z}$-score of the $1^{\text {st }}$ and the $2^{\text {nd }}$ cluster are similar overall in all the variables studied except one - time orientation, while Type One shows lower future time orientation and Type Two - on the contrary - above-average high.

The variables of achievement-oriented behaviour, aspiration level and perseverance differentiate between Type One, Type Two and Type Three, however, these two types are similar in the level of time orientation.

Table 1. Average z-scores for three types in the three-cluster solution

\begin{tabular}{lccc}
\hline & $\begin{array}{c}\text { Type 1 } \\
(\mathrm{N}=\mathbf{8 0})\end{array}$ & $\begin{array}{c}\text { Type 2 } \\
(\mathrm{N}=73)\end{array}$ & $\begin{array}{c}\text { Type 3 } \\
(\mathrm{N}=60)\end{array}$ \\
\hline Academic performance & -0.01 & 0.05 & -0.05 \\
\hline Achievement-oriented behaviour & -0.23 & -0.51 & 0.93 \\
\hline Aspiration level & -0.27 & -0.47 & 0.92 \\
\hline Perseverance & -0.21 & -0.59 & 1.00 \\
\hline Time orientation & -0.33 & 3.03 & 2.85 \\
\hline
\end{tabular}

Graph 1. Three-cluster solution: profiles of average z-scores for the variables studied

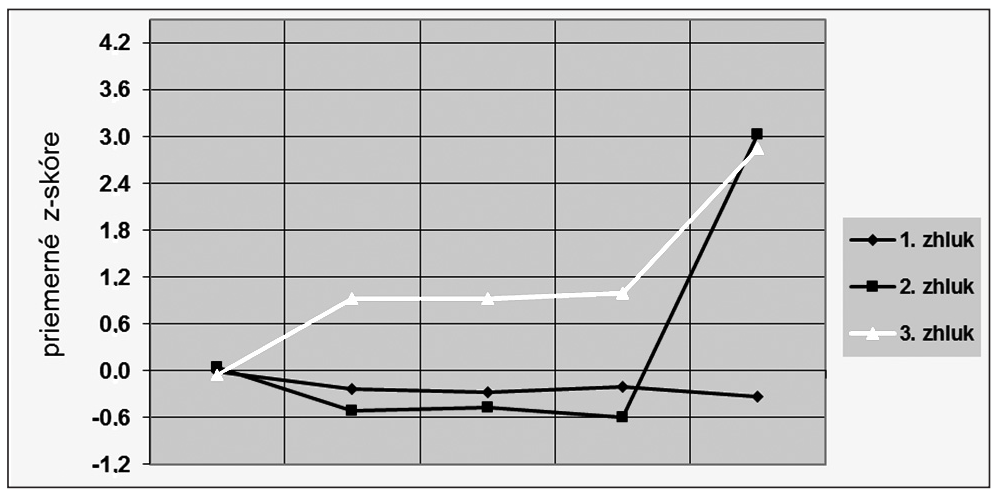

Legend: priemerné z-skóre = average z-scores; zhluk = cluster

Since the three-cluster solution appeared little specific, the process of cluster analysis was continued - a request for generation of four clusters was entered. The solution is presented in Table 2 and Graph 2.

Type One within the given solution is represented by students with - regarding the other respondents - worse academic performance, poorer achievement-oriented behaviour, an average aspiration level and lower perseverance, but good time orientation. 
Type Two is characterized by above-average academic performance, but a low level of achievement-oriented behaviour and a low aspiration level, low perseverance as well as under-average future time orientation.

Type Three is distinguished by average academic performance and an above-average level of all achievement motive components, marked above-average is in the variable time orientation.

Type four is identified under-average (poorer) academic performance, a slightly above-average level of the achievement motive variables, and average time orientation.

Table 2. Average z-scores for four types in the four-cluster solution

\begin{tabular}{lcccc}
\hline & $\begin{array}{c}\text { Type 1 } \\
(\mathrm{N}=71)\end{array}$ & $\begin{array}{c}\text { Type 2 } \\
(\mathrm{N}=38)\end{array}$ & $\begin{array}{c}\text { Type 3 } \\
(\mathrm{N}=50)\end{array}$ & $\begin{array}{c}\text { Type 4 } \\
(\mathrm{N}=54)\end{array}$ \\
\hline Academic performance & -0.11 & 0.36 & 0.17 & -0.27 \\
\hline Achievement-oriented behaviour & -0.35 & -1.02 & 0.95 & 0.30 \\
\hline Aspiration level & -0.33 & -1.05 & 0.97 & 0.28 \\
\hline Perseverance & -0.52 & -0.84 & 1.13 & 0.23 \\
\hline Time orientation & 3.17 & -0.32 & 3.04 & 0.02 \\
\hline
\end{tabular}

Graph 2. Four-cluster solution: average z-score profiles for the variables studied

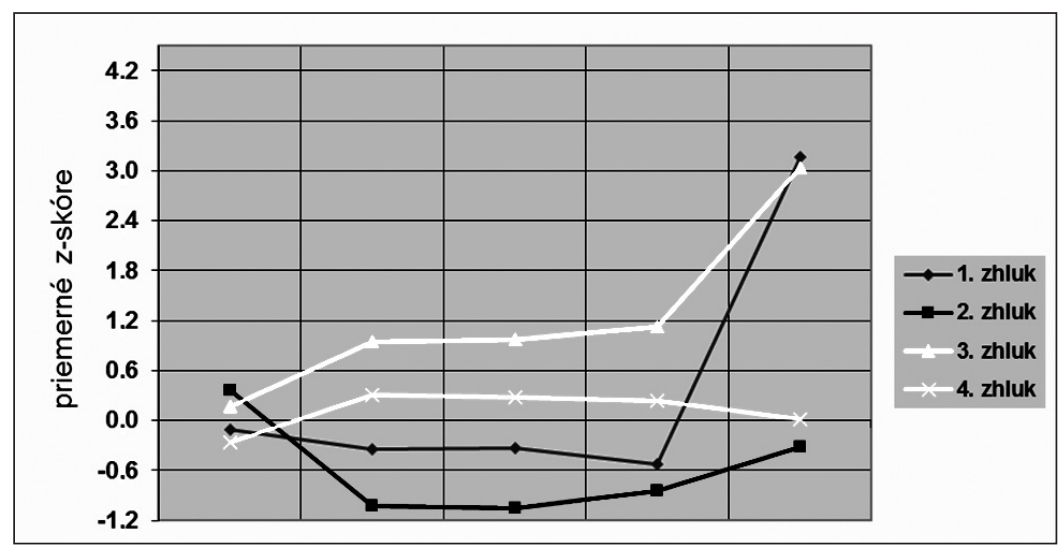

Legend: priemerné z-skóre = average $\mathrm{z}$-scores; zhluk = cluster

In the next - five-type - solution, again higher differentiation and specification of types was achieved against the previous one (Table 3, Graph 3).

Type One within the given solution may be marked as under-average in all the 
variables studied. Thus, it is an unsuccessful as well as unmotivated student with low achievement motivation and a poor planning ability.

Type Two resembles Type Two generated within the previous solution (above-average academic performance, but an under-average level of other variables).

Type Three has average academic performance, but good indicators in the achievement motive items (especially as far as time orientation is concerned).

Type Four is distinguished by poorer academic performance, but above-average achievement motivation indicators (this type may be assumed to have insufficient abilities).

Type Five in the four-cluster solution is characterized by average academic performance, a lower level of achievement-oriented behaviour and perseverance, as well as a lower aspiration level, but is above-average concerned with future and plans ahead.

Table 3. Average z-scores for five types in the five-cluster solution

\begin{tabular}{llllll}
\hline & $\begin{array}{c}\text { Type 1 } \\
(\mathrm{N}=28)\end{array}$ & $\begin{array}{c}\text { Type 2 } \\
(\mathrm{N}=37)\end{array}$ & $\begin{array}{c}\text { Type 3 } \\
(\mathrm{N}=34)\end{array}$ & $\begin{array}{c}\text { Type 4 } \\
(\mathrm{N}=47)\end{array}$ & $\begin{array}{c}\text { Type 5 } \\
(\mathrm{N}=67)\end{array}$ \\
\hline Academic performance & -0.62 & 0.64 & 0.08 & -0.28 & 0.06 \\
\hline Achievement-oriented behaviour & -0.76 & -0.44 & 0.92 & 0.83 & -0.49 \\
\hline Aspiration level & -0.71 & -0.40 & 0.87 & 0.74 & -0.44 \\
\hline Perseverance & -1.06 & 0.09 & 1.07 & 0.64 & -0.60 \\
\hline Time orientation & -0.48 & -0.42 & 4.06 & 1.13 & 3.04 \\
\hline
\end{tabular}

Graph 3. Five-cluster solution: average z-score profiles for the variables studied

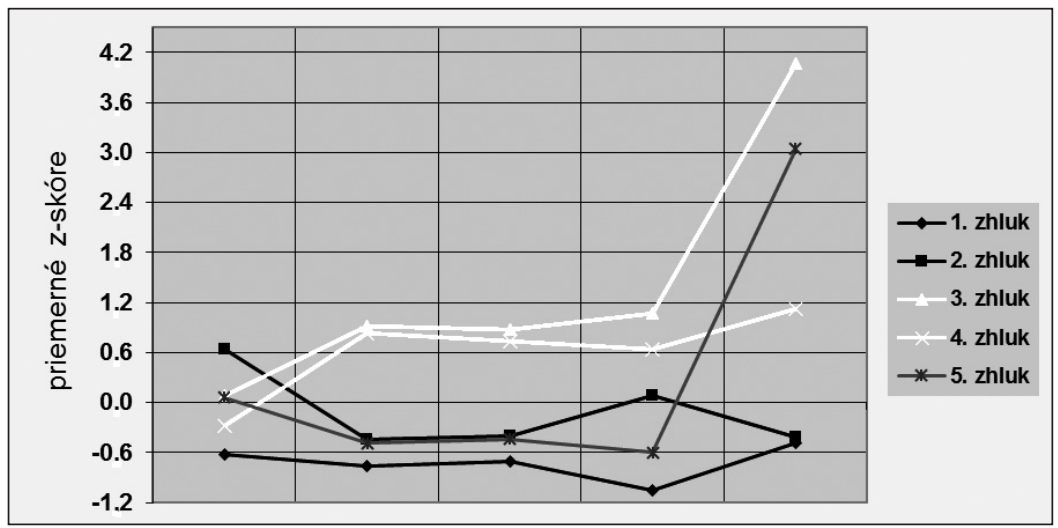

Legend: priemerné z-skóre = average z-scores; zhluk = cluster 
Refining and specification of the type profiles was continued by generating a six-cluster solution.

Type One is represented by the students with better academic performance in comparison with the others, but a lower aspiration level as well as a lower level of achievement-oriented behaviour and perseverance, and a slightly under-average level of future time orientation (this type is profiled almost identically with Type One in the previous - five-cluster - solution).

Type Two (analogous to Type Five of the previous solution) is characterized by average academic performance and poorer achievement-oriented behaviour, a lower aspiration level and perseverance, on the other hand, however, marked future time orientation.

Type Three is represented by the students with above-average academic performance and overall good achievement motive indicators (levels of achievement variables are about the same).

Type Four shows poorer academic performance, average achievement-oriented behaviour, an average aspiration level and perseverance, but under-average future time orientation.

Type Five has poor academic performance, average achievement-oriented behaviour, an average aspiration level and perseverance, but high future time orientation.

Type Six has slightly above-average academic performance, is the most markedly achievement-motivated when compared with the others and future time orientation also reaches the highest level in this type.

Table 4. Average z-scores for six types in the six-cluster solution

\begin{tabular}{lcccccc}
\hline & $\begin{array}{c}\text { Type 1 } \\
(\mathrm{N}=33)\end{array}$ & $\begin{array}{c}\text { Type 2 } \\
(\mathrm{N}=47)\end{array}$ & $\begin{array}{c}\text { Type 3 } \\
(\mathrm{N}=38)\end{array}$ & $\begin{array}{c}\text { Type 4 } \\
(\mathrm{N}=34)\end{array}$ & $\begin{array}{c}\text { Type 5 } \\
(\mathrm{N}=34)\end{array}$ & $\begin{array}{c}\text { Type 6 } \\
(\mathrm{N}=27)\end{array}$ \\
\hline Academic performance & 0.54 & 0.34 & 0.44 & -0.66 & -0.96 & 0.17 \\
\hline $\begin{array}{l}\text { Achievement-oriented } \\
\text { behaviour }\end{array}$ & -1.10 & -0.59 & 0.66 & 0.00 & 0.29 & 1.09 \\
\hline Aspiration level & -1.12 & -0.45 & 0.80 & 0.02 & 0.01 & 0.99 \\
\hline Perseverance & -0.82 & -0.67 & 0.80 & -0.12 & 0.01 & 1.20 \\
\hline Time orientation & -0.23 & 3.26 & 0.97 & -0.60 & 2.64 & 4.21 \\
\hline
\end{tabular}

The cluster structure of our sample was refined even further - a request was entered to generate a seven-cluster solution. However, based on the assessment of the statistic indicators examined (results of variance analysis within the individual 
Graph 4. Six-cluster solution: average z-score profiles for the variables studied

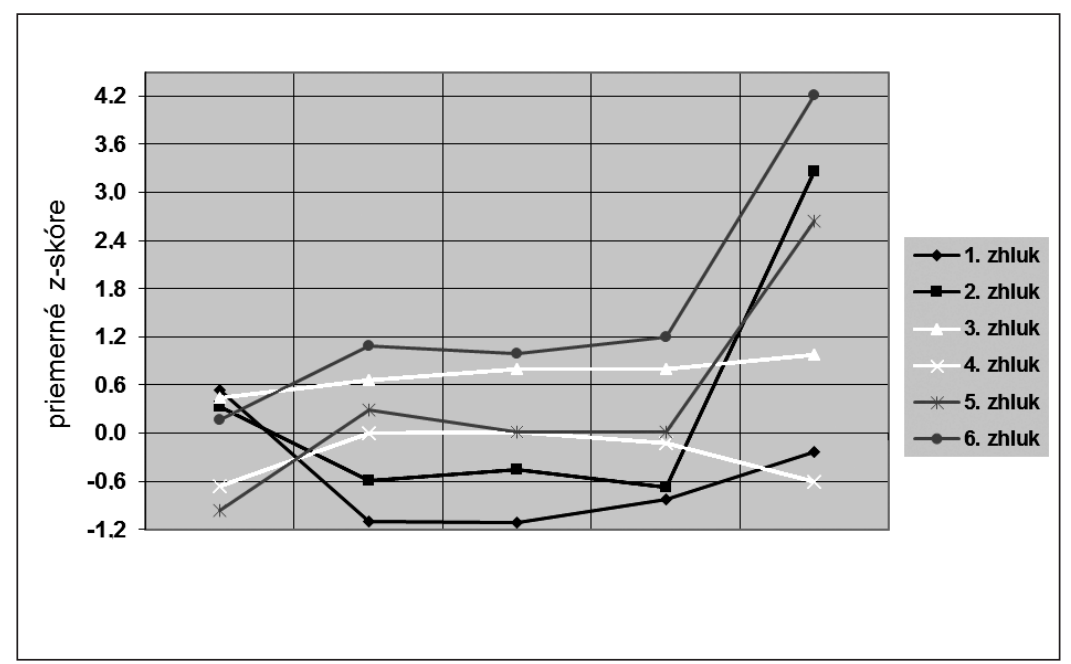

Legend: priemerné z-skóre = average z-scores; zhluk = cluster

solutions and standard deviations of the variables within individual clusters in the 5-, 6- and 7-cluster solutions) the six-cluster solution was preferred. This solution can, in our view, be considered also relatively clear and meaningful.

Next, we attempted to find other specifics of these six types by including in the analysis also the gender variable (as the so-called external variable, i.e. a variable not entering into the clustering process). It was found out that the gender variable differentiated in Type Three (Balanced) was composed mostly of men, and in Type Five (Academically Indifferent) was composed mostly of women.

\section{Discussion}

The typologies with three to six types were extracted gradually by means of non-hierarchical cluster analysis. For the sake of better clarity and comprehension as well as their simpler communicability, the types generated within the six-cluster solution were given names. Type One with the best academic performance, but the lowest level of all achievement variables was called the Type of Unused Potential. Type Two was called the Unbalanced Type due to the unbalanced levels of achievement variables. Type Three - with above-average academic performance as 
well as above-average achievement variables was given the name of Balanced Type. This is precisely the type that seems to be ideal in terms of success achievement. Type Four, markedly characterized especially by under-average future time orientation, was called the Type Unoriented in Time. Type Five with poor academic performance, average achievement indicators, but high future time orientation was called the Academically Indifferent Type. Finally, Type Six, with the most marked achievement motivation, but basically just average academic performance, was called the Industrious Type.

On the basis of our findings, it may be stated that our research sample consists of students with above-average academic performance, but low achievement variables (Type 1), as well as students achieving an average to above-average level of achievement variables, but with an average or even under-average level of academic performance (Type 5 and Type 6). These findings bring out the issue of the generalized nature of achievement motivation. Some, even highly achievement motivated students, have poorer academic performance. Thus, it may be assumed that it is important for student achievement motivation to focus on learning tasks, academic success. B. Weiner (1990; as cited in: Bong, 2004) already argued that the original view on achievement motivation as a stable individual characteristic did not explain its situational variability, which may have manifested itself also in our case. That is the reason why we agree with M. Vaněk, V.Hošek and F. Man (1982), according to whom it may be assumed that instead of the conception of the generalized nature of achievement motivation, performance is influenced by a specific achievement motive focused on activities in which an individual feels, e.g. competent or which supports his/her interests.

\section{Conclusion}

The relationship between the achievement motivation components and academic performance was dealt with by several authors (Kolb, 1965; Řehulková, Osecká, 1996; Skinner, J. M. Drake, 2003; Gurgová, 2005). The relationship between the school-related self-concept (Engler-Meyer) and achievement motivation was dealt with by L. Duricová (2009), who pointed out mainly the negative consequences of high anxiety on an individual's self-concept. Z. Vašašová (2011) pointed out positive relationships between emotional experiencing and performance (in the area of creative activities). Academic performance and its various connections 
were studied by S. Shim and A. Ryan (2005), W. E. Kelly (2003), T. L. Clemons (2005), K. E. Barron (2006).

From the point of view of educational practice, in addition to academic performance, also the individual aspects of achievement motive are important (achievement-oriented behaviour, aspiration level, perseverance at work, future time orientation). Our research pointed at the fact that undergraduate students include also types of students who, although having good academic performance, have a poor achievement motive, or students having poorer or average academic performance, but high levels of the achievement motive aspects. We believe that the ideal type of students are, of course, those who, on the one hand, achieve high results and, on the other hand, have a high aspiration level, perseverance at work and future time orientation, because these are the motives likely to predispose a student to success also in future practice, not only in the academic setting.

\section{References}

Barron, K.E. et al. (2006). Achievement goals of students with ADHD. Learning Disability Quarterly, Vol. 29, pp. 137-158.

Bong, M. (2004). Academic motivation in self-efficacy, task value, achievement goal orientations, and attributional beliefs. The Journal of Educational Research, July/August, Vol. 97, No. 6, pp. 287-297.

Clemons, L.T. (2005). Underachieving gifted students: A social cognitive model. University of Virginia: Thesis, 127 p. ISBN 0-542-31942-X.

Duricová, L. (2009). Self-concept of University Students and Their Motivation. The New Educational Review, Vol. 17, No. 1, pp. 264-275, ISSN 1732-6729

Gurgová, B. (2005). Vztah výkonovej motivácie a školskej úspešnosti. Psychológia v škole [electronic source]. Banská Bystrica: PF UMB. ISBN 80-8083-165-3. pp. 207-210.

Kelly, W.E. (2003). As achiement sails the river of time: The role of time use efficiency in grade-point-average. Educational Research Quarterly, Vol. 27.4, pp.3-8.

Kolb, D.A. (1965). Achievement motivation training for underachieving high-school boys. Journal of Personality and Social Psychology, Vol. 2, No. 6, pp. 783-792.

McClelland, D.C. et al. (1976). The achievement motive. New York: Halsted Press. 385 p. ISBN 0-470-01390-7

McLellan, R., Adey, P. (1999). Motivation style, commitment, and cognitive acceleration: Is it only good schools which opt into "successful" projects? Paper presented at the annual meeting of the american educational research association (Montreal, Quebec, Canada), 19-23 April. From EBSCO HOST.

Nakonečný, M. (1996). Motivace lidského chování. Praha: ACADEMIA, 268 p. ISBN 80-200-0592-7. 
Nakonečný, M. (2000). Sociální psychologie. Praha: ACADEMIA, 282 p. ISBN 80-200-0690-7.

Neumeister, K.L.S., Finch, H. (2006). Perfectionism in High-Ability Students: Relational Precursors and Influences on Achievement Motivation. The Gifted Child Quarterly; Summer, Vol. 50, No. 3; pp. 238-251.

Osecká, L. (2001). Typologie v psychologii. Aplikace metod zhlukové analýzy v psychologickém výzkumu. Praha: Academia, p. 155 ISBN 80-200-0854-3

Pardel, T., Maršálová, L., Hrabovská, A. (1984). Dotazník motivácie výkonu. Príručka. Bratislava: Psychodiagnostika, 48 p.

Řehulková, O., Osecká, L. (1996). Výkonová motivace ve škole. (Výskumná správa). Brno: Psychologický ústav, $13 \mathrm{p}$.

Shim, S., Ryan, A. (2005). Changes in Self-Efficacy, Challenge Avoidance, and Intrinsic Value in Response to Grades: The Role of Achievement Goals. The Journal of Experimental Education, Vol. 73, N. 4, pp. 333-349.

Skinner, N.F., Drake, J.M. (2003). Behavioral implications of adaption-innovation: III. adaption-innovation, achievement motivation, and academic performance. Social Behavior and Personality, Vol. 31, No. 1, pp. 101-106.

Vaněk, M., Hošek, V., Man, F. (1982). Formování výkonové motivace. Praha: UK, 201 p.

Vašašová, Z. (2011). Relations between creativity and the personal charakteristics of man. The New Educational Review. Poland - Toruń: Adam Marszalek, 2011, Vol. 24, No. 2. pp. 57-69, ISSN 1732-6729. 